\title{
Biosorption of Lead, Mercury, and Cadmium Ions by Aspergillus terreus Immobilized in a Natural Matrix
}

\author{
YIH-MIN SUN ${ }^{1}$, CHING-YI HORNG ${ }^{2}$, FU-LIN CHANG ${ }^{1 *}$, LI-CHUN CHENG ${ }^{3}$, WEN-XUAN TIAN ${ }^{1}$ \\ ${ }^{1}$ Department of Occupational Safety and Health, Chung Hwa University of Medical Technology, Tainan 717, Taiwan \\ ${ }^{2}$ Department of Occupational Safety and Health, Chang Jung Christian University, Tainan 711, Taiwan \\ ${ }^{3}$ Department of Environment and Safety Health, Chung Hwa University of Medical Technology, Tainan 717, Taiwan
}

Received 20 November 2009, revised 2 February 2010, accepted 5 February 2010

\begin{abstract}
Our aim was to investigate the biosorption of $\mathrm{Pb}^{2+}, \mathrm{Hg}^{2+}, \mathrm{Cd}^{2+}$ from aqueous solution by Aspergillus terreus (both free and immobilized on loofa sponge discs). Our results show that the adsorption capacity of fungal biomass on loofa sponge (FBLS) is superior to free fungal biomass (FFB). The adsorption selectivity by FBLS was in the order $\mathrm{Pb}^{2+}>\mathrm{Hg}^{2+}>\mathrm{Cd}^{2+}$. The maximum metal ions adsorbed was $247.2,37.7$, $23.8 \mathrm{mg} / \mathrm{g} \mathrm{FBLS}$ for $\mathrm{Pb}^{2+}, \mathrm{Hg}^{2+}$ and $\mathrm{Cd}^{2+}$, respectively. Metal uptake by FBLS was affected by the $\mathrm{pH}$ of the metal solution, but independent of temperature $\left(10-50^{\circ} \mathrm{C}\right)$. The Langmuir model was more suitable than the Freundlich model to describe the biosorption process of FBLS. The regenerated FBLS was found to be effective for repeated use for five cycles without significant loss in adsorption capacity. This research demonstrates that FBLS possesses excellent capacity for $\mathrm{Pb}^{2+}$ biosorption from aqueous solution and industrial wastewaters.
\end{abstract}

K e y w o rd s: biosorption, heavy metal, immobilization, industrial wastewater

\section{Introduction}

It is well recognized that the presence of heavy metals in the environment can be detrimental to a variety of living species, including man. Industrial wastewaters are considered the most important source of heavy metal pollution. The conventional technologies for treating these pollutants are precipitation, oxidation/reduction, ion exchange, filtration and electrolysis. However, some disadvantages, such as high cost, incomplete removal, high energy consumption, and/or generation of toxic wastes accompany these technologies. Therefore, a cost-effective treatment that efficiently removes heavy metals from industrial effluents is needed. Using microorganisms (i.e., fungi, bacteria, algae and yeasts) as biosorbents to remove metal ions from wastewater offers a potential alternative to existing methods. Numerous studies have demonstrated that microorganisms have ability to remove heavy metals from wastewater with better performance and lower cost compared with conventional technologies (Congeevaram et al. 2007, Kapoor et al., 1999; Liu et al., 2004; Moon et al., 2006).
Aspergillus, Penicillum and Trichoderma are the primary fungal groups that degrade cellulose, hemicellulose and lignin in agriculture wastes, soils, and the feces of cattle and sheep. Among the three fungal groups, Aspergillus spp. are the most frequently studied and applied in agriculture waste recycling and the biomass energy industry (Gawande and Kamat, 1999, 2000; Ghanem et al., 2000). Various researchers have investigated the use of Aspergillus spp. as a biosorbent for metal ions removal. For example, studies have shown that Aspergillus niger can effectively remove uranium, lead, cadmium and copper ions (Kapoor et al., 1999; Yakubu and Dudeney, 1986). Huang and Huang (1996) and Huang et al., (1988) investigated the use of Aspergillus oryzae to remove cadmium and copper ions from aqueous solution. A strain of Aspergillus terreus has been shown to take up chromium, nickel and iron from metallurgical effluents (Dias et al., 2002).

Small particle size with low density, poor mechanical strength and rigidity are some of the physical problems encountered when applying biomass as

* Corresponding author: F.L. Chang, Department of Occupational Safety and Health, Chung Hwa University of Medical Technology, No. 89, Wen-Hwa $1^{\text {st }}$ St., Rende Shiang Tainan County 717, Taiwan, R.O.C.; phone: 886-6-2671214 ext. 803; fax: 886-6-2902464; e-mail: fulin@mail.hwai.edu.tw 
a biosorbent (Han et al., 2005; McHale and McHale, 1994). Immobilization of the biomass within a suitable matrix can overcome these problems by offering ideal size, mechanical strength, rigidity and porous characteristics to the biological material (Trujillo et al., 1995). Several immobilized biomass systems have been successfully used as adsorbing agents to remove heavy metals (Blanco et al., 1999; Hu and Reeves, 1997; Pan et al., 2005). Among the various immobilized biomass systems, a polymeric matrix is the most common method. However, these techniques have certain disadvantages: they are prohibitively expensive, they limit the rate of diffusion ( $\mathrm{Hu}$ and Reeves, 1997), or they produce other waste products that require disposal (Wilde and Benemann, 1993).

Loofa sponge is a natural, environmentally friendly biomaterial. It is abundant, cheap, rigid, non-toxic, chemically inert and highly porous. The use of loofa sponge material for the immobilization of algae, fungal hyphae and yeast cells has been successfully demonstrated (Akhtar et al., 2008; Iqbal and Edyvean, 2004; Iqbal and Zafar, 1994; Li et al., 2008; Ogbonna et al., 2001). However, the use of loofa sponge-immobilized Aspergillus terreus for metal biosorption has not been investigated. Our previous report showed that free A. terreus has high capacity for adsorbing metal ions from aqueous solutions (Ho et al., 2006). The goal of the present study was to further investigate $\mathrm{Pb}^{2+}, \mathrm{Hg}^{2+}$ and $\mathrm{Cd}^{2+}$ biosorption from solutions by loofa spongeimmobilized A. terreus. and to evaluate the applicability of the immobilized $A$. terreus for the removal of $\mathrm{Pb}^{2+}$ from real industrial wastewaters.

\section{Experimental}

\section{Materials and Methods}

Microorganism and culture medium. The fungus, Aspergillus terreus BCRC 32068, was obtained from the Bioresource Collection and Research Center, HsinChu, Taiwan. It was maintained in pure culture with potato dextrose agar (Difco) slants at $28^{\circ} \mathrm{C}$. After incubating for 7 days, fungal spores were harvested with sterile solution $(0.9 \% \mathrm{NaCl}, 0.05 \%$ Tween 80$)$, washed twice and enumerated. An aliquot amount of fungal spores $\left(2 \times 10^{6}\right)$ was transferred to a $250-\mathrm{ml}$ Erlenmeyer flask containing $50 \mathrm{ml}$ of growth medium (Hajjaj et al., 2001). This growth medium consisted of $5 \mathrm{~g} \mathrm{l}^{-1} \quad \mathrm{KH}_{2} \mathrm{PO}_{4}, 5 \mathrm{~g} \mathrm{l}^{-1} \quad \mathrm{~K}_{2} \mathrm{HPO}_{4}, 0.2 \mathrm{~g} \mathrm{l}^{-1}$ $\mathrm{FeSO}_{4} \times 7 \mathrm{H}_{2} \mathrm{O}, 0.1 \mathrm{~g} \mathrm{l}^{-1} \mathrm{MnSO}_{4} \times 4 \mathrm{H}_{2} \mathrm{O}, 0.2 \mathrm{~g} \mathrm{l}^{-1}$ $\mathrm{ZnSO}_{4} \times 7 \mathrm{H}_{2} \mathrm{O}, 5 \mathrm{mg} \mathrm{l}^{-1} \mathrm{CuCl}_{2} \times 2 \mathrm{H}_{2} \mathrm{O}, 11 \mathrm{mg} \mathrm{l}^{-1}$ $\mathrm{H}_{3} \mathrm{BO}_{3}, 5 \mathrm{mg} \mathrm{l}^{-1}\left(\mathrm{NH}_{4}\right)_{6} \mathrm{Mo}_{7} \mathrm{O}_{24} \times 4 \mathrm{H}_{2} \mathrm{O}, 12.5 \mathrm{~g} \mathrm{l}^{-1}$ $\mathrm{C}_{5} \mathrm{H}_{8} \mathrm{NNaO}_{4}, 45 \mathrm{~g} \mathrm{l}^{-1}$ glucose, $0.1 \mathrm{~g} \mathrm{l}^{-1} \mathrm{MgSO}_{4} \times 7 \mathrm{H}_{2} \mathrm{O}$, and $20 \mathrm{mg} \mathrm{l}^{-1} \mathrm{CaCl}_{2} \times 2 \mathrm{H}_{2} \mathrm{O}$. Once inoculated, the flasks were shaken in an incubator shaker (200 rpm) at $28^{\circ} \mathrm{C}$ for $24 \mathrm{~h}$. These mycelium suspensions were then used for immobilization.

Pretreatment of the loofa sponge. Vegetable sponges composed of loofa, Luffa aegyptica, were purchased from the Madou local market (Tainan, Taiwan). They were used as immobilized media for A. terreus. The fibrous sponges were cut into discs of approximately $0.2 \mathrm{~g}$, soaked in boiling water for $30 \mathrm{~min}$, thoroughly washed under tap water, soaked for 24 hours and rinsed for 3-4 times with deionized water. Then, the sponge discs were sterilized by autoclaving at $121^{\circ} \mathrm{C}$ for $30 \mathrm{~min}$. Finally, the sponge discs were oven dried at $70^{\circ} \mathrm{C}$ and stored in desiccators before further use.

Immobilization of $\boldsymbol{A}$. terreus on loofa sponge discs. The immobilizing technique was performed according to the method described by Iqbal and Edyvean (2004), with some modifications.

An aliquot amount (approximately $2.5 \mathrm{ml}$ ) of mycelium suspension was taken from the fungal stock culture and inoculated into $250 \mathrm{ml}$ flasks containing $50 \mathrm{ml}$ of the growth medium and four pre-weighed loofa sponge discs. Culture flasks for free hyphal growth, with no loofa sponge discs in the medium, served as the control. The inoculated flasks were then incubated at $28^{\circ} \mathrm{C}$ and shaken at $200 \mathrm{rpm}$. After 15 days of incubation, both free (hereafter called free fungal biomass and abbreviated as FFB) and immobilized A.terrues (hereafter called fungal biomass on loofa sponge and abbreviated as FBLS) were harvested from the medium, rinsed twice with distilled water and oven dried at $70^{\circ} \mathrm{C}$. The dry weight of the fungal biomass entrapped within the sponge discs was determined by weighing the sponge discs before and after fungal growth following $24 \mathrm{~h}$ of drying at $70^{\circ} \mathrm{C}$.

Metal solutions. All reagents used were analytical-grade. The stock solutions of $\mathrm{Pb}^{2+}, \mathrm{Hg}^{2+}$ and $\mathrm{Cd}^{2+}$ (6000 $\mathrm{mg} \mathrm{l}^{-1}$ for $\mathrm{Pb}^{2+}, 2000 \mathrm{mg} \mathrm{l}^{-1}$ for $\mathrm{Hg}^{2+}$ and $2000 \mathrm{mg}^{-1}$ for $\mathrm{Cd}^{2+}$ ) were prepared by dissolving exact quantities of $\mathrm{PbCl}_{2}, \mathrm{HgCl}_{2}$ and $\mathrm{CdCl}_{2} \times 2 \mathrm{H}_{2} \mathrm{O}$ in doubly distilled water, respectively. The working solutions containing single $\mathrm{Pb}^{2+}$ or $\mathrm{Hg}^{2+}$ or $\mathrm{Cd}^{2+}$ were prepared just before use by diluting the stock solutions. The initial metal ion concentration ranged from 1000 to $6000 \mathrm{mg} \mathrm{l}^{-1}$, in the case of $\mathrm{Pb}^{2+}$ and from 200 to $2000 \mathrm{mg} \mathrm{l}^{-1}$, in the case of $\mathrm{Hg}^{2+}$ and $\mathrm{Cd}^{2+}$. Except for a $\mathrm{pH}$-shift experiment, the $\mathrm{pH}$ of the working solution was adjusted to $\mathrm{pH} 5.0$ with $0.1 \mathrm{~N} \mathrm{HCl}$ or $0.1 \mathrm{~N} \mathrm{NaOH}$.

Biosorption studies. Batch experiments were conducted to determine the optimum $\mathrm{Pb}^{2+}, \mathrm{Hg}^{2+}$ and $\mathrm{Cd}^{2+}$ biosorption conditions. One hundred milligrams of FBLS or FFB were mixed with $100 \mathrm{ml}$ of the metal solutions $\left(6000 \mathrm{mg} \mathrm{l}^{-1}\right.$ for $\mathrm{Pb}^{2+}, 800 \mathrm{mg} \mathrm{l}^{-1}$ for $\mathrm{Hg}^{2+}$ and $300 \mathrm{mg} \mathrm{l}^{-1}$ for $\mathrm{Cd}^{2+}$ ) in $250 \mathrm{ml}$ Erlenmeyer flasks. The effects of contact time, $\mathrm{pH}$, temperature and rotation speed on the biosorption of $\mathrm{Pb}^{2+}, \mathrm{Hg}^{2+}$ and $\mathrm{Cd}^{2+}$ were studied. The effect of contact time was evaluated 
in the range of 10-180 min. The flasks were agitated on an orbital shaker $(200 \mathrm{rpm})$ at $30^{\circ} \mathrm{C}$. In the latter experiments the contact time of 90 min was applied. The effect of $\mathrm{pH}$ on the biosorption capacity was investigated at initial $\mathrm{pH}$ values range of 2.0-6.0. The designated $\mathrm{pH}$ of the solutions was achieved by adding $\mathrm{HCl}$ or $\mathrm{NaOH}$ at the beginning of the experiment without further adjustment afterwards. As above, the flasks were agitated on an orbital shaker (200 rpm) at $30^{\circ} \mathrm{C}$. In experiments to test the effect of temperature, the flasks were agitated $(200 \mathrm{rpm})$ at different temperatures ranging from 10 to $50^{\circ} \mathrm{C}$. In experiments to find the effect of rotation speeds, the flasks were agitated at $30^{\circ} \mathrm{C}$ using different agitation speeds $(0,50,100$, 150, 200 and $250 \mathrm{rpm}$ ). In experiments to assess the effect of the initial metal ion concentration, $100 \mathrm{ml}$ of single metal solutions (1000-6000 mg ${ }^{-1}$ for $\mathrm{Pb}^{2+}$,

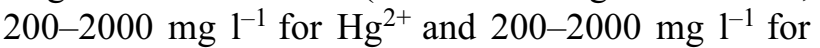
$\mathrm{Cd}^{2+}$ ) were contacted with $100 \mathrm{mg}$ of FBLS for $90 \mathrm{~min}$ at $200 \mathrm{rpm}$ and $30^{\circ} \mathrm{C}$. At the end of biosorption, FFB was removed from metal solution by centrifugation at $1500 \mathrm{~g}$ for $5 \mathrm{~min}$, whereas FBLS was separated from the solution by simple decantation. Residual metal concentrations in the supernatant were determined using an atomic absorption spectrophotometer (PerkinElmer AAnalyst 1003). The adsorption efficiency of metals by FBLS and FFB were then derived.

All glassware for the biosorption experiments was cleaned by immersion in $10 \% \mathrm{HNO}_{3}$ overnight and extensive flushing with deionized water.

Data analyses. The biosorption capacities for metal ions adsorbed per unit weight of FFB and FBLS were determined by Equation (1).

$$
q=V\left(C_{i}-C_{e q}\right) / M
$$

where $\mathrm{q}$ is the metal uptake capacity (mg metal ions/g dry weight of fungal biomass); $\mathrm{V}$ is the volume of metal solution (1); $\mathrm{C}_{\mathrm{i}}$ is the initial concentration of metal ions in the solution $\left(\mathrm{mg} \mathrm{l}^{-1}\right) ; \mathrm{C}_{\mathrm{eq}}$ is the residual concentration of metal ions in the solution $\left(\mathrm{mg} \mathrm{l}^{-1}\right)$; $\mathrm{M}$ is the dry weight of fungal biomass (g). All experiments were replicated in triple runs.

The Langmuir and Fruendlich equilibrium models were used to describe our equilibrium batch sorption tests. Langmuir isotherm assumes monolayer adsorption, and is presented by the $\mathrm{Eq}(2)$.

$$
q_{\mathrm{e}}=\left(q_{\max } K_{L} C_{\mathrm{e}}\right) /\left(1+K_{L} C_{\mathrm{e}}\right)
$$

where $q_{\mathrm{e}}$ and $q_{\max }$ are the equilibrium and maximum uptake capacities ( $\mathrm{mg} / \mathrm{g}$ biosorbent); $C_{\mathrm{e}}$ is the equilibrium concentration ( $\mathrm{mg} \mathrm{l}^{-1}$ ); and $K_{L}$ is the equilibrium constant $(1 / \mathrm{mg})$.

The Freundlich isotherm model is presented by Eq (3).

$$
q_{e}=K_{F} C_{e}{ }^{1 / n}
$$

where $K_{F}$ and $n$ are Freundlich constants that characterize the system.

Desorption studies. For batch desorption studies, five different desorbing agents $\left(0.1 \mathrm{~N} \mathrm{HNO}_{3}, 0.1 \mathrm{~N} \mathrm{HCl}\right.$,
$0.1 \mathrm{~N} \mathrm{CH}_{3} \mathrm{COOH}, 0.1 \mathrm{~N} \mathrm{H}_{2} \mathrm{SO}_{4}$ and deionized $\mathrm{H}_{2} \mathrm{O}$ ) were used. One hundred milligrams of FBLS were contacted with $100 \mathrm{ml}$ of $6000 \mathrm{mg} \mathrm{l}^{-1}$ of $\mathrm{Pb}^{2+}$ solution for biosorption and $100 \mathrm{ml}$ desorption solution for desorption in $250 \mathrm{ml}$ Erlenmeyer flasks. The flasks were agitated on an orbital shaker $(200 \mathrm{rpm})$ at $30^{\circ} \mathrm{C}$. The contact time of biosorption and desorption was maintained $90 \mathrm{~min}$ for achieving biosorption or desorption equilibrium. The amount of $\mathrm{Pb}^{2+}$ adsorbed on FBLS was obtained by difference between the initial $\mathrm{Pb}^{2+}$ concentration and the final one after biosorption equilibrium was reached. After desorption, the FBLS was removed and the final $\mathrm{Pb}^{2+}$ concentration in the aqueous phase was determined by atomic absorption spectrophotometer. The desorption ratio was calculated from the amount of $\mathrm{Pb}^{2+}$ adsorbed on FBLS and the final $\mathrm{Pb}^{2+}$ concentration in the desorbing agent.

In order to determine reusability of the biosorbent, the FBLS was reused in five biosorption-desorption cycles. After each cycle of biosorption-desorption, FBLS was recovered by decantation, washed repeatedly with distilled water and reconditioned for biosorption in the succeeding cycle.

\section{Results and Discussion}

Immobilization of $A$. terreus on loofa sponge discs. The biomasses of $A$. terreus hypha grown on the loofa sponge discs in 30-day incubation were monitored. Serving as a growth substratum, the porous sponges did have a positive influence on the growth of $A$. terreus. Typical exponential growth curves were observed after the first 5 days, and, probably due to the complete coverage of the sponges by fungal hypha, reached a stationary phase on the seventh day (data not shown).

In order to examine whether the biosorption of FBLS depends on the growth phases of $A$. terreus, the lead uptake by FBLS in different incubation periods $(3,7,15,18,23$ and 30 days) were compared. The results show that the $\mathrm{Pb}^{2+}$ adsorption, with fixed concentration of $6000 \mathrm{mg} \mathrm{l}^{-1} \mathrm{of} \mathrm{Pb}^{2+}$, increased as the incubation time of FBLS increased (Fig. 1). The lead uptake capacity increased remarkably when the immobilized $A$. terreus cells were in stationary phase ( $7^{\text {th }}$ day; Fig. 1). The highest lead uptake was observed on day 15. However, the lead uptake decreased significantly for incubation time longer than 18 days. Based on these observations, we chose 15 days as the optimal incubation period for preparing FBLS in subsequent experiments.

Chemical and physical stability of FBLS. The chemical and physical stability of biosorbents are important in wastewater treatment (Gadd and White, 1993). FBLS was immersed in a $\mathrm{pH}$ neutral solution 


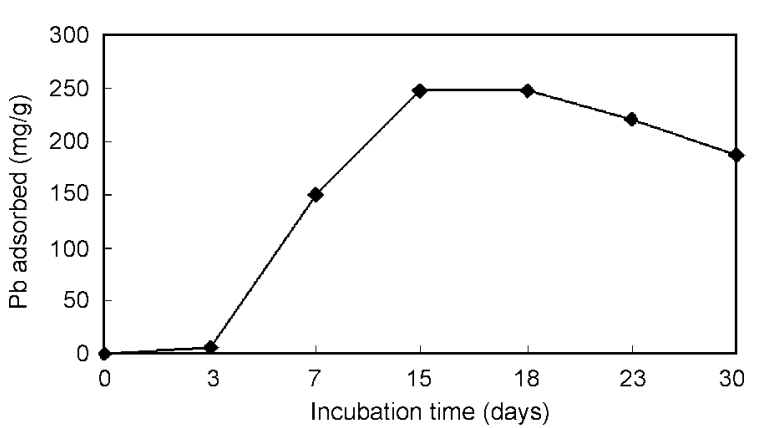

Fig. 1. Effect of growth phase on lead uptake by FBLS. Biosorption conditions: concentration of $\mathrm{Pb}^{2+}: 6000 \mathrm{mg} \mathrm{l}^{-1}, \mathrm{pH} 5$, temperature: $30^{\circ} \mathrm{C}$, FBLS: $100 \mathrm{mg}$, rotation speed: $200 \mathrm{rpm}$, contact time: $90 \mathrm{~min}$.

for 20 days on a rotary shaker at different rotation speeds (50-300 rpm) at $30^{\circ} \mathrm{C}$. No significant mechanical effect on FBLS was observed (Fig. 2). While immersing the FBLS in buffer solutions of $\mathrm{pH}$ ranging from 2.0 to 12.0 for 20 days (at $30^{\circ} \mathrm{C}$ and $200 \mathrm{rpm}$ ), no noticeable corrosive effect on FBLS was observed (Fig. 2).

Effect of contact time on biosorption. The kinetic profiles of metal ions biosorption by FBLS and FFB are shown in Fig. 3. The lead uptake by these biosorbents was found to be extremely rapid, reaching an equilibrium in 20 and 10 min for FBLS and FFB, respectively. After reaching equilibrium, the amount of lead adsorbed did not change significantly over time. The maximum lead uptake capacity of FBLS is superior to that of FFB. This may be due to an increase in accessible binding sites on FBLS. On the other hand, the equilibrium biosorptions of cadmium and mercury ions onto both tested biosorbents were evidently low. The difference in sorption dynamics and capacity for different metals by the biosorbents has been explained in terms of the difference in the ionic size of metals, ionic radii, electrode potential, affinity to the functional groups on the biosorbents, as well as the mode of interaction between the metal ions and the biosorbent (Chandra Sekhar et al., 2004).
Effect of pH on metal ion biosorption. It is well known that the biosorption of heavy metal ions onto fungal biomass is affected by $\mathrm{pH}$ (Iqbal and Edyvean, 2005). In fact, metals not only show different $\mathrm{pH}$ optima for their sorption, but may also vary from one kind of biosorbent to another. In order to evaluate the effect of $\mathrm{pH}$ on the amount of metal uptake by FBLS and $\mathrm{FFB}$, the batch studies of different $\mathrm{pH}$, ranging from 2.0 to 6.0, were conducted. As can be seen from Fig. 4, the $\mathrm{pH}$ has a profound influence on metal sorption by both FBLS and FFB. The metal uptake by FBLS and FFB were significantly low at $\mathrm{pH} 2.0$ and then suddenly increased in $\mathrm{pH}$ from 2.0 to 3.0. For the lead adsorpted on FBLS, the biosorption plateau was attained at $\mathrm{pH}$ ranging from 3.0 to 5.0. This may be due to the large quantities of proton competing with the metal cations for the adsorption sites at $\mathrm{pH} 2.0$ (Huang et al., 1988). As the $\mathrm{pH}$ of the solution increases, the number of protons dissociated from the functional groups on the fungal cell wall increases and thus more negative-charge groups for the complexation of metal cations are provided. A similar result is reported (Yan and Viraraghavan, 2003) for the removal of lead using Penicillium digitatum and Rhizopus nigricans. Removal of lead, copper and zinc by Phanerochaete chrysosporium (Iqbal and Edyvean, 2004) also shows the same trend. It is notable that the metal uptake by FBLS has a milder $\mathrm{pH}$-dependent effect than that of FFB (Fig. 4). Because most metal contaminated industrial wastewater is acidic, the $\mathrm{pH}$ resistant property of FBLS may be advantageous for industrial applications.

Effect of temperature on metal ion biosorption. We conducted batch studies at different temperatures, ranging from 10 to $50^{\circ} \mathrm{C}$. The results for FBLS and FFB are shown in Figure 5. There is no obvious difference for the amount of metal uptake by FBLS among different temperatures. However, higher metal uptakes at elevated temperatures were observed for FFB. This might be due to the increases in the binding sites by disaggregating the fungal pellets at higher

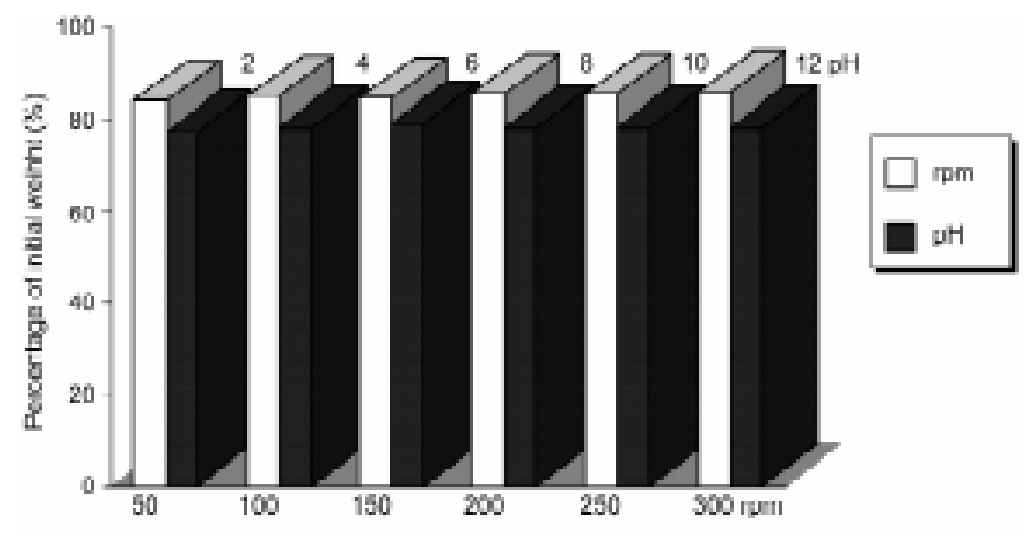

Fig. 2. Physical and chemical stability of FBLS 


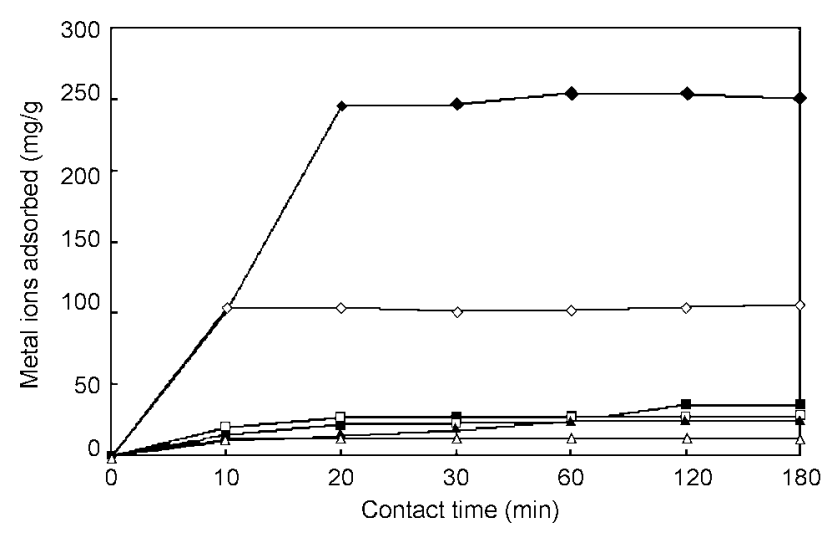

Fig. 3. Biosorption kinetics of metal ions by FBLS and FFB; 100 $\mathrm{ml}$ single metal solutions $\left(\mathrm{Pb}^{2+}=6000 \mathrm{mg} \mathrm{l}^{-1}, \mathrm{Hg}^{2+}=800 \mathrm{mg} \mathrm{l}^{-1}\right.$, $\mathrm{Cd}^{2+}=300 \mathrm{mg} \mathrm{l}^{-1}$ ) were contacted with $100 \mathrm{mg}$ of FBLS or FFB. Biosorption conditions: $\mathrm{pH}$ 5, temperature: $30^{\circ} \mathrm{C}$, rotation speed: 200 rpm. (FBLS: $\mathrm{Pb}(\diamond), \operatorname{Hg}(\boldsymbol{\square}), \mathrm{Cd}(\boldsymbol{\Delta})$; FFB: $\mathrm{Pb}(\diamond), \operatorname{Hg}(\square), \mathrm{Cd}(\Delta)$.

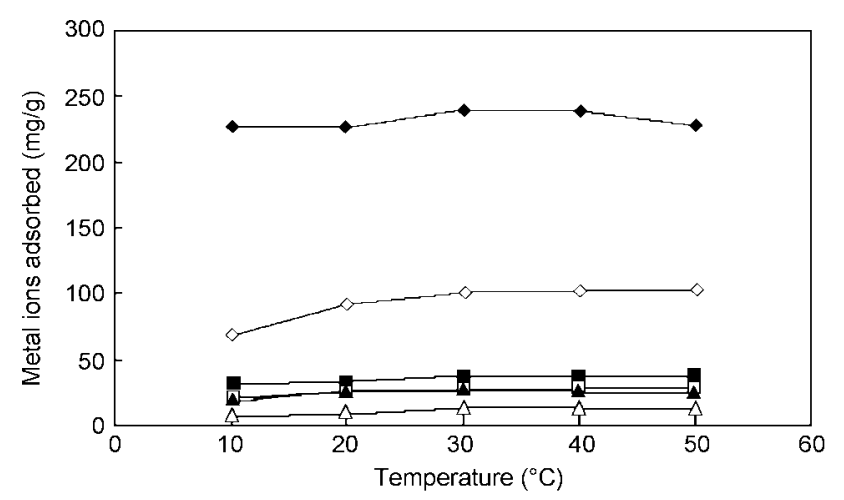

Fig. 5. The effect of temperature on metal ions biosorption by FBLS and FFB. $100 \mathrm{ml}$ single metal solutions $\left(\mathrm{Pb}^{2+}=6000 \mathrm{mg} \mathrm{l}^{-1}\right.$, $\mathrm{Hg}^{2+}=800 \mathrm{mg} \mathrm{l}^{-1}, \mathrm{Cd}^{2+}=300 \mathrm{mg} \mathrm{l}^{-1}$ ) were contacted with $100 \mathrm{mg}$ of FBLS or FFB. Biosorption conditions: $\mathrm{pH}$ 5, rotation speed: 200 rpm, contact time: 90 min. (FBLS: $\mathrm{Pb}(\bullet), \operatorname{Hg}(\boldsymbol{\square}), \mathrm{Cd}(\boldsymbol{\Delta})$; FFB: $\operatorname{Pb}(\diamond), \operatorname{Hg}(\square), \operatorname{Cd}(\Delta)$.

temperatures (Iqbal and Edyvean, 2004). The thermal stability of FBLS makes it more suitable than FFB for industrial applications.

Effect of rotation speed on metal ion biosorption. We conducted batch studies of different rotation speeds, ranging from 0 to $250 \mathrm{rpm}$. The results are shown in Figure 6. Metal uptake by both FBLS and FFB increased with increasing rotation speed, especially in the case of lead adsorption by FBLS. Furthermore, FBLS with a stereo matrix shows a stronger affect by rotation speed, in comparison with FFB without the physical structure. The enhanced sorption ability at higher rotation speeds is probably due to an increase in the mobility of the sorbing species (Bulut and Baysal, 2006).

Effect of initial metal ion concentration. Heavy metal ion biosorption capacities of FBLS are presented as a function of the initial concentration of $\mathrm{Pb}^{2+}, \mathrm{Hg}^{2+}$ and $\mathrm{Cd}^{2+}$ within the aqueous solution in

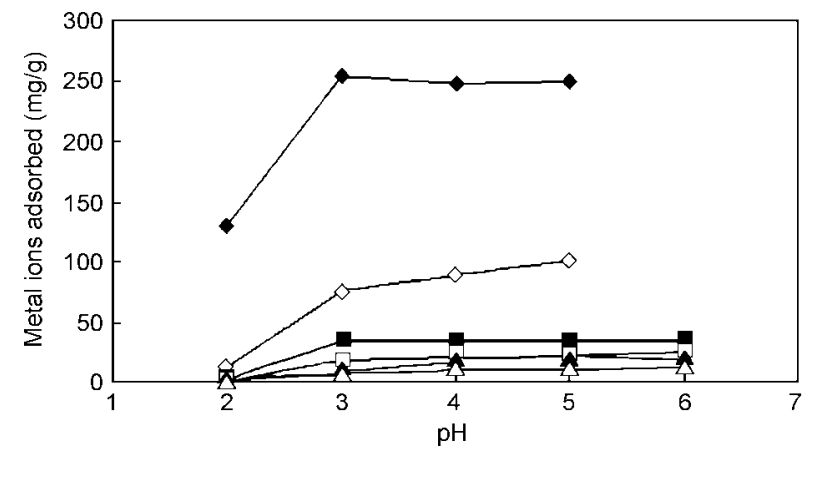

Fig. 4. Effect of $\mathrm{pH}$ on metal ions biosorption by FBLS and FFB; $100 \mathrm{ml}$ single metal solutions $\left(\mathrm{Pb}^{2+}=6000 \mathrm{mg} \mathrm{l}^{-1}, \mathrm{Hg}^{2+}=800 \mathrm{mg} \mathrm{l}^{-1}\right.$, $\mathrm{Cd}^{2+}=300 \mathrm{mg} \mathrm{l}^{-1}$ ) were contacted with $100 \mathrm{mg}$ of FBLS or FFB. Biosorption conditions: temperature: $30^{\circ} \mathrm{C}$, rotation speed: $200 \mathrm{rpm}$, contact time: $90 \mathrm{~min}$. (FBLS: $\mathrm{Pb}(\diamond), \operatorname{Hg}(\mathbf{\square}), \mathrm{Cd}(\boldsymbol{\Delta})$; FFB: $\operatorname{Pb}(\diamond), \operatorname{Hg}(\square), \operatorname{Cd}(\Delta)$.

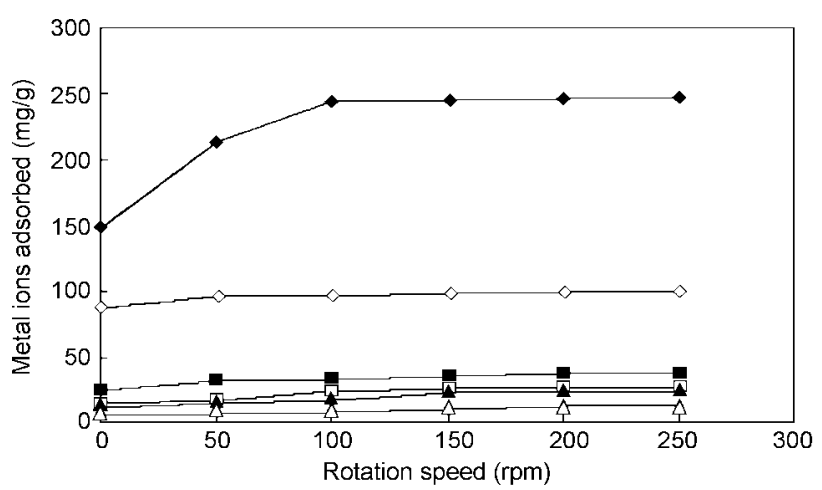

Fig. 6. The effect of rotation speed on metal ions biosorption by FBLS and FFB. $100 \mathrm{ml}$ single metal solutions $\left(\mathrm{Pb}^{2+}=6000 \mathrm{mg} \mathrm{l}^{-1}\right.$, $\mathrm{Hg}^{2+}=800 \mathrm{mg} \mathrm{l}^{-1}, \mathrm{Cd}^{2+}=300 \mathrm{mg} \mathrm{l}^{-1}$ ) were contacted with $100 \mathrm{mg}$ of FBLS or FFB. Biosorption conditions: $\mathrm{pH}$ 5, temperature: $30^{\circ} \mathrm{C}$, contact time: 90 min. (FBLS: $\mathrm{Pb}(\diamond), \mathrm{Hg}(\boldsymbol{\square}), \mathrm{Cd}(\boldsymbol{\Delta})$; FFB: $\operatorname{Pb}(\diamond), \operatorname{Hg}(\square), \operatorname{Cd}(\Delta)$.

Fig. 7. These experiments were performed for $90 \mathrm{~min}$ using single metal solutions $\left(\mathrm{Pb}^{2+}: 1000-6000 \mathrm{mg} \mathrm{l}^{-1}\right.$, $\mathrm{Hg}^{2+}:$ 200-2000 $\mathrm{mg} \mathrm{l}^{-1}, \mathrm{Cd}^{2+}: 200-2000 \mathrm{mg} \mathrm{l}^{-1}$ ) at $\mathrm{pH}$ 5.0. Figure 7 shows that the metal ion biosorption capacity of FBLS increased with the increase in initial concentration of metal ions. This trend was also observed for the removal of lead and copper by Phanerochaete chrysosporium (Iqbal and Edyvean, 2004). It is worth mentioning that the isotherms for all three metals were steep at lower concentrations, indicating the suitability of FBLS for treatment of dilute solutions.

Adsorption isotherms. In order to determine the biosorption isotherm model of FBLS, we examined the most widely used isotherm models: Langmuir and Freundlich. The Langmuir isotherm assumes a monolayer adsorption while the Freundlich isotherm is an empirical equation based on sorption at a heterogeneous surface. Our results suggest that the Langmuir model is better than the Freundlich model 

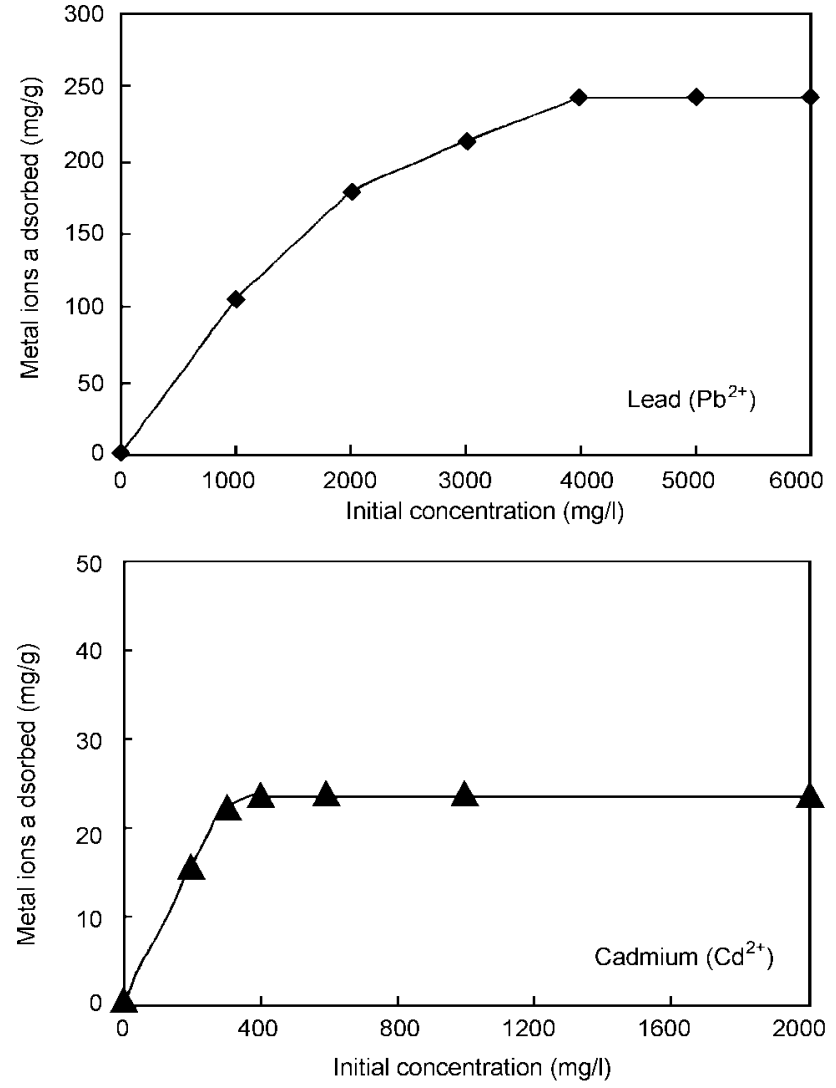

in describing the experimental data. Model parameters for $\mathrm{Pb}^{2+}, \mathrm{Hg}^{2+}$ and $\mathrm{Cd}^{2+}$ were further calculated (Table I). The excellent correlation coefficients $\left(\mathrm{r}^{2}>0.99\right)$ for all the three metal ions tested clearly indicate that the Langmuir isotherm model is suitable for describing the biosorption isotherms of FBLS in the studied concentration ranges. Higher $\mathrm{q}_{\max }$ values for $\mathrm{Pb}^{2+}$, as compared to $\mathrm{Hg}^{2+}$ and $\mathrm{Cd}^{2+}$ confirm the stronger bonding affinity of FBLS to $\mathrm{Pb}^{2+}$ than that of $\mathrm{Hg}^{2+}$ and $\mathrm{Cd}^{2+}$.

Table I

Parameters of Langmuir and Freundlich biosorption model of FBLS

\begin{tabular}{|c|c|c|c|c|c|c|}
\hline \multirow{2}{*}{$\begin{array}{c}\text { Metal } \\
\text { ions }\end{array}$} & \multicolumn{3}{|c|}{ Langmuir model } & \multicolumn{3}{c|}{ Freundlich model } \\
\cline { 2 - 7 } & $q_{\max }(\mathrm{mg} / \mathrm{g})$ & $K_{L}(1 / \mathrm{mg})$ & $R^{2}$ & $K_{F}$ & $n$ & $R^{2}$ \\
\hline $\mathrm{Pb}^{2+}$ & 253.16 & 0.01 & 0.999 & 57.68 & 0.18 & 0.724 \\
\hline $\mathrm{Hg}^{2+}$ & 41.26 & 0.02 & 0.997 & 7.75 & 0.26 & 0.806 \\
\hline $\mathrm{Cd}^{2+}$ & 25.72 & 0.07 & 0.999 & 6.69 & 0.24 & 0.853 \\
\hline
\end{tabular}

Biosorption studies. We conducted biosorption tests for 90 min using single-metal solutions $\left(\mathrm{Pb}^{2+}=\right.$ $\left.6000 \mathrm{mg} \mathrm{l}^{-1}, \mathrm{Hg}^{2+}=800 \mathrm{mg} \mathrm{l}^{-1}, \mathrm{Cd}^{2+}=300 \mathrm{mg} \mathrm{l}^{-1}\right)$ at $\mathrm{pH}$ 5.0. Table II demonstrates that the metal uptake capacity by FBLS is better than both FFB and a naked loofa sponge. Moreover, the selectivity by the biosorbent was in the order of $\mathrm{Pb}^{2+}>\mathrm{Hg}^{2+}>\mathrm{Cd}^{2+}$. One can conclude that the binding sites for metal ions are located on the $A$. terreus cell walls and immobilization does not alter the binding sites and binding ability of

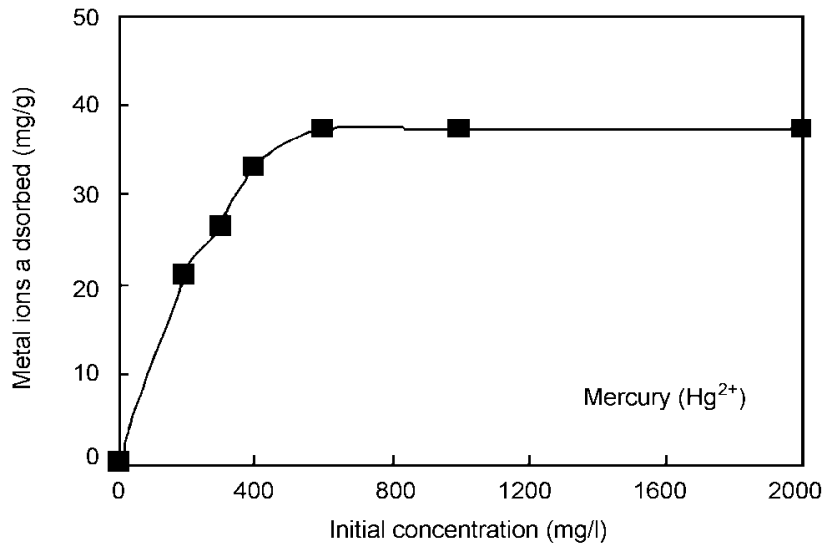

Fig. 7. The effect of initial metal concentration on metal ions biosorption by FBLS; $100 \mathrm{ml}$ single metal solutions (1000-6000 $\mathrm{mg}^{-1}$ for $\mathrm{Pb}^{2+}$, 200-2000 $\mathrm{mg} \mathrm{l}^{-1}$ for $\mathrm{Hg}^{2+}$ and 200-2000 $\mathrm{mg} \mathrm{l}^{-1}$ for $\mathrm{Cd}^{2+}$, $\mathrm{pH}$ 5.0) were contacted with $100 \mathrm{mg}$ of FBLS for $90 \mathrm{~min}$ at $30^{\circ} \mathrm{C}$, 200 rpm. $(\mathrm{Pb}(\bullet), \operatorname{Hg}(\boldsymbol{\square}), \mathrm{Cd}(\boldsymbol{\Delta})$.

FBLS. Lower adsorption rates of metal uptake by FFB may be attributed to aggregated fungal hypha biomass, thus reducing their exposure surface area for sorption. Higher metal uptake by FBLS is due to hypha immobilization along the surface of the fibrous thread, no aggregate formation, and the open network of the loofa sponge. These all enhance the surface area and free access of metal ions to the sorption sites (Akhtar et al., 2004). Increase in metal uptake by FBLS further indicates no limitations in the movement of metal ions or the masking of active sites by the loofa matrix, unlike other reported systems such as immobilization of a mixture of microorganisms from activated sludge on hydrogels where significant decreases in the rate of metal sorption occur (Gourdon et al., 1990).

Biosorption in mixed-metal system. We tested the biosorption of metal ions by both FBLS and FFB

Table II

Biosorption capacity of biosorbent for $\mathrm{Pb}^{2+}, \mathrm{Hg}^{2+}$ and $\mathrm{Cd}^{2+}$; experiments were conducted in $100 \mathrm{ml}$ single metal solution $\left(\mathrm{Pb}^{2+}=6000 \mathrm{mg} \mathrm{l}^{-1}, \mathrm{Hg}^{2+}=800 \mathrm{mg} \mathrm{l}^{-1}, \mathrm{Cd}^{2+}=300 \mathrm{mg} \mathrm{l}^{-1}\right)$ at optimal condition $\left(\mathrm{pH} 5.0\right.$, temperature: $30^{\circ} \mathrm{C}$, rotation speed: $200 \mathrm{rpm}$, amount of biosorbent: $100 \mathrm{mg}$ )

\begin{tabular}{|l|c|c|c|}
\hline \multirow{2}{*}{ Biosorbents } & \multicolumn{3}{|c|}{ Metal adsorbed (mg/g biosorbents) } \\
\cline { 2 - 4 } & $\mathrm{Pb}^{2+}$ & $\mathrm{Hg}^{2+}$ & $\mathrm{Cd}^{2+}$ \\
\hline FBLS & 247.23 & 37.68 & 23.82 \\
\hline FFB & 106.6 & 26.6 & 12.85 \\
\hline Loofa sponge & 13.125 & 6.77 & 4.97 \\
\hline
\end{tabular}




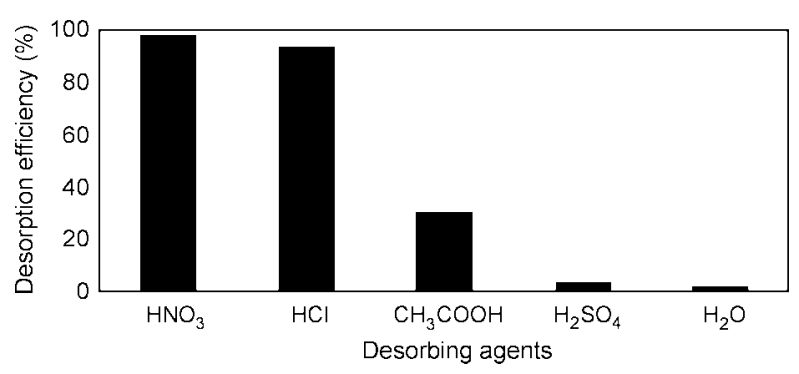

Fig. 8. Desorption efficiency of $\mathrm{Pb}^{2+}$ from FBLS by various desorbing agents.

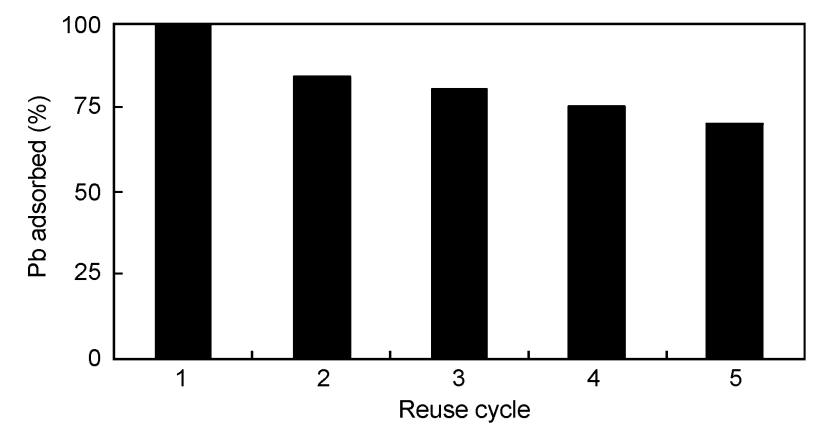

Fig. 10. Biosorption of $\mathrm{Pb}^{2+}$ by FBLS in five consecutive adsorption-desorption cycles.

in a mixed-metal system to determine the synergistic/ antagonistic effect of cations present in the effluent metal solution. We tested metal solutions containing either one metal alone $\left(6000 \mathrm{mg} \mathrm{l}^{-1}\right)$ or mixed with one another (3000 $\mathrm{mg} \mathrm{l}^{-1}$ per metal) or two other metals (2000 $\mathrm{mg} \mathrm{l}^{-1}$ per metal). Table III shows the metal removal percentage obtained with FBLS when mixedmetal solutions were used. The presence of other cations reduced the sorption capacity of $\mathrm{Pb}^{2+}, \mathrm{Hg}^{2+}$ and $\mathrm{Cd}^{2+}$. The milder influence of $\mathrm{Hg}^{2+}$ and $\mathrm{Cd}^{2+}$ on $\mathrm{Pb}^{2+}$ biosorption could be due to the greater atomic weight, electronegativity, and atom radius of these two metals

Table III

Effect of other ions on biosorption of $\mathrm{Pb}^{2+}, \mathrm{Hg}^{2+}$ and $\mathrm{Cd}^{2+}$ by FBLS; $100 \mathrm{ml}$ metal solutions containing either one metal alone $\left(6000 \mathrm{mg} \mathrm{l}^{-1}\right)$ or mixed with one other $\left(3000 \mathrm{mg}^{-1}\right.$ per metal) or two others (2000 $\mathrm{mg} \mathrm{l}^{-1}$ per metal) were contacted with $100 \mathrm{mg}$ of FBLS for $90 \mathrm{~min}$ at $30^{\circ} \mathrm{C}, 200 \mathrm{rpm}$

\begin{tabular}{|l|c|c|c|}
\hline \multirow{2}{*}{$\begin{array}{c}\text { Interfering } \\
\text { ions }\end{array}$} & \multicolumn{4}{|c|}{$\begin{array}{c}{ }^{\mathrm{a}} \text { metal recovered on FBLS when } \\
\text { the interfering ions were present }\end{array}$} \\
\cline { 2 - 4 } & $\mathrm{Pb}$ & $\mathrm{Hg}$ & $\mathrm{Cd}$ \\
\hline None & 100 & 100 & 100 \\
\hline $\mathrm{Pb}$ & - & 30 & 13 \\
\hline $\mathrm{Hg}$ & 99 & - & 49 \\
\hline $\mathrm{Cd}$ & 98 & 62 & - \\
\hline $\mathrm{Pb}+\mathrm{Hg}$ & - & - & 30 \\
\hline $\mathrm{Pb}+\mathrm{Cd}$ & - & 57 & - \\
\hline $\mathrm{Hg}+\mathrm{Cd}$ & 97.5 & - & - \\
\hline
\end{tabular}

${ }^{\text {a }}$ Mean of 3 determinations

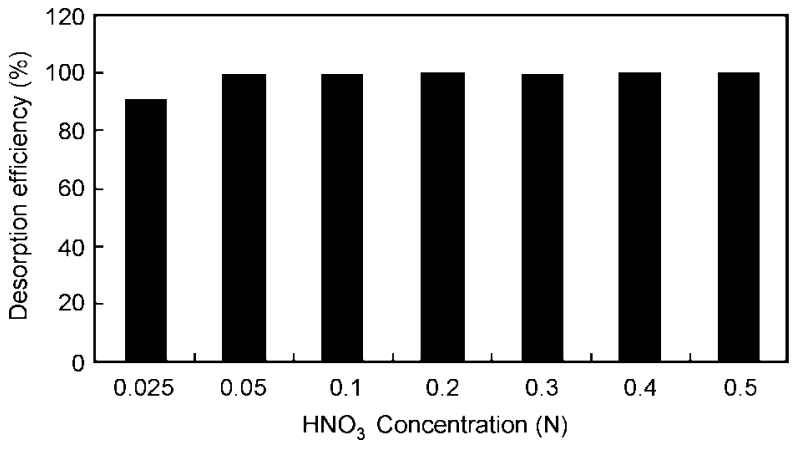

Fig. 9. Effect of $\mathrm{HNO}_{3}$ concentrations on the desorption efficiency of $\mathrm{Pb}^{2+}$ from FBLS.

(Tsekova and Petrov, 2002). When all the three metals were presented, FBLS adsorbed the metal ions in the following order: $\mathrm{Pb}^{2+}>\mathrm{Hg}^{2+}>\mathrm{Cd}^{2+}$. Our study shows that $A$. terreus greatly favors $\mathrm{Pb}^{2+}$ adsorption.

Desorption and regeneration. We conducted desorption tests to determine the suitable eluant and its applicable concentration. We tested five desorbing agents, $0.1 \mathrm{~N}$ sulfuric acid, $0.1 \mathrm{~N}$ acetic acid, $0.1 \mathrm{~N}$ hydrochloric acid, $0.1 \mathrm{~N}$ nitric acid and deionized water. The portions of $\mathrm{Pb}^{2+}$ desorbed from the metalsaturated FBLS by the various desorbing agents are shown in Fig. 8. It is clear that nitric acid has a better desorption efficiency than the others. Therefore, we selected it as the desirable eluant for the studies. We conducted other desorption experiments to determine optimum concentrations for the desorbing agent $\mathrm{HNO}_{3}$. For practical applications, the concentration of acid solution used for the recovery of metals should be as low as possible. Biomass loaded with $\mathrm{Pb}^{2+}$ was contacted with $\mathrm{HNO}_{3}$ solutions of different concentrations for $60 \mathrm{~min}$. We determined the amount of $\mathrm{Pb}^{2+}$ released back into the $\mathrm{HNO}_{3}$ solution and expressed it as desorption efficiency. The results show that increasing the concentrations of $\mathrm{HNO}_{3}$ increased the desorption efficiency (Fig. 9). Nitric acid with the concentration of $0.05 \mathrm{~N}$ or higher can remove more than $99.0 \%$ of adsorbed $\mathrm{Pb}^{2+}$. Therefore, we used $0.05 \mathrm{~N}$ nitric acid as the eluant in the subsequent studies.

The purpose of regenerating the biosorbent is to cut down operating costs. We examined the feasibility of regenerating metal-adsorbed FBLS by $0.05 \mathrm{~N}$ nitric acid by repeating the adsorption-desorption process for five consecutive cycles. Results demonstrate that FBLS retained its metal adsorption capacity after five regenerating cycles (Fig. 10). The deterioration in sorption capacity of FBLS for $\mathrm{Pb}^{2+}$ after five cycles remained at $78 \%$, which suggests that FBLS has the potential to adsorb $\mathrm{Pb}^{2+}$ ions repeatedly from aqueous solution. The deterioration effect on metal adsorption may be due to the physical damage of the FBLS caused by the desorbing agent used in the regeneration cycles. 
To evaluate the potential of FBLS for the removal of $\mathrm{Pb}^{2+}$ from a real industrial wastewater, we placed the FBLS into a flask containing the industrial effluent $\left(\mathrm{Pb}^{2+}: 236.8-255.8 \mathrm{mg} \mathrm{l}^{-1}\right)$. The $\mathrm{Pb}^{2+}$ biosorption capacity of the FBLS in the batch experiment (contact at $\mathrm{pH} 5.0,200 \mathrm{rpm}$ and $30^{\circ} \mathrm{C}$ for $90 \mathrm{~min}$ ) was $183.6 \mathrm{mg} \mathrm{Pb}^{2+} / \mathrm{g}$ FBLS. The results show that FBLS has potential for commercial applications.

\section{Acknowledgements}

The authors gratefully acknowledge financial support provided by the National Science Council of Taiwan under Grant No. 93-2211-E-273-003.

\section{Literature}

Akhtar N., J. Iqbal and M. Iqbal. 2004. Removal and recovery of nickel(II) from aqueous solution by loofa sponge-immobilized biomass of Chlorella sorokiniana: characterization studies. J. Hazard. Mater. B108: 85-94.

Akhtar N., M. Iqbal, S.I. Zafar and J. Iqbal. 2008. Biosorption characteristics of unicellular green alga Chlorella sorokiniana immobilized in loofa sponge for removal of $\mathrm{Cr}(\mathrm{III})$. J. Environ. Sci. 20: 231-239.

Blanco A., B. Sanz, M.J. Llama and J.L. Serra. 1999. Biosorption of heavy metals to immobilized Phormidium Laminosum biomass. J. Biotechnol. 69: 227-240.

Bulut Y. and Z. Baysal. 2006. Removal of $\mathrm{Pb}$ (II) from wastewater using wheat bran. J. Environ. Manage. 78: 107-113.

Chandra Sekhar K., C.T. Kamala, N.S. Chary, A.R.K. Sastry, T. Nageswara Rao and M. Vairamani. 2004. Removal of lead from aqueous solutions using an immobilized biomaterial derived from a plant biomass. J. Hazard. Mater. B108: 111-117.

Congeevaram S., S. Dhanarani, J. Park, M. Dexilin and K. Thamaraiselvi. 2007. Biosorption of chromium and nickel by heavy metal resistant fungal and bacterial isolates. J. Hazard. Mater. 146: 270-277.

Dias M.A., I.C.A. Lacerda, P.F. Pimentel, H.F. de Castro and C.A. Rosa. 2002. Removal of heavy metals by an Aspergillus terreus strain immobilized in a polyurethane matrix. Lett. Appl. Microbiol. 34: 46-50.

Gadd G.M. and C. White. 1993. Microbial treatment of metal pollution - a working biotechnology? Trends Biotechnol. 11: 353-359.

Gawande P.V. and M.Y. Kamat. 1999. Production of Aspergillus xylanase by lignocellulosic waste fermentation and its application. J. Appl. Microbiol. 87: 511-519.

Gawande P.V. and M.Y. Kamat. 2000. Production of xylanases by immobilized Aspergillus sp. using lignocellulosic waste. World J. Microb. Biot. 16: 111-112.

Ghanem N.B., H.H. Yusef and H.K. Mahrouse. 2000. Production of Aspergillus terreus xylanase in solid-state cultures: application of the Plackett-Burman experimental design to evaluate nutritional requirements. Bioresour. Technol. 73: 113-121.

Gourdon R., S. Bhende, E. Rus and S.S. Sofer. 1990. A comparative study of cadmium uptake by free and immobilized cells from activated sludge. J. Environ. Sci. Heal. A 25: 1019-1036.

Hajjaj H., P. Niederberger and P. Duboc. 2001. Lovastatin biosynthesis by Aspergillus terreus in a chemically defined medium. Appl. Environ. Microbiol. 67: 2596-2602.
Han R., J. Zhang, W. Zou, J. Shi and H. Liu. 2005. Equilibrium biosorption isotherm for lead ion on chaff. J. Hazard. Mater. B125: 266-271.

Ho T.H., W.T. Li, Y.M. Sun and F.L. Chang. 2006. The effect of environmental factors on the adsorption of heavy metals from water by Aspergillus terreus (in Chinese). J. Natl. Kaohsiung Univ. Appl. Sci. 35: 335-346.

Hu M.Z.C. and M. Reeves. 1997. Biosorption of uranium by Pseudomonas aeruginosa strain CSU immobilized in a novel matrix. Biotechnol. Progr. 13: 60-70.

Huang C. and C.P. Huang. 1996. Application of Aspergillus oryzae and Rhizopus oryzae for Cu (II) removal. Water Res. 30: 1985-1990.

Huang C.P., D. Westman, C. Huang and A.L. Morehart. 1988. The removal of cadmium (II) from dilute aqueous solutions by fungal biosorbent. Water Sci. Technol. 20: 369-376.

Iqbal M. and R.G.J. Edyvean. 2004. Biosorption of lead, copper and zinc ions on loofa sponge immobilized biomass of Phanerochaete chrysosporium. Miner. Eng. 17: 217-223.

Iqbal M. and R.G.J. Edyvean. 2005. Loofa sponge immobilized fungal biosorbent: A robust system for cadmium and other dissolved metal removal from aqueous solution. Chemosphere 61: 510-518.

Iqbal M. and S.I. Zafar. 1994. Vegetable sponge as a matrix to immobilize microorganisms: a trial study for hyphal fungi, yeast and bacteria. Lett. Appl. Microbiol. 18: 214-217.

Kapoor A., T. Viraraghavan and D. Roy Cullimore. 1999. Removal of heavy metals using the fungus Aspergillus niger. Bioresour. Technol. 70: 95-104.

Li X.M., D.X. Liao, X.Q. Xu, Q. Yang, G.M. Zeng, W. Zheng and L. Guo. 2008. Kinetic studies for the biosorption of lead and copper ions by Penicillium simplicissimum immobilized within loofa sponge. J. Hazard. Mater. 159: 610-615.

Liu H.L., B.Y. Chen, Y.W. Lan and Y.C. Cheng. 2004. Biosorption of $\mathrm{Zn}(\mathrm{II})$ and $\mathrm{Cu}(\mathrm{II})$ by the indigenous Thiobacillus thiooxidans. Chem. Eng. J. 97: 195-201.

McHale A.P. and S. McHale. 1994. Microbial biosorption of metals: Potential in the treatment of metal pollution. Biotechnol. Adv. 12: 647-652.

Moon S.H., C.S. Park, Y.J. Kim and Y.I. Park. 2006. Biosorption isotherms of $\mathrm{Pb}(\mathrm{II})$ and $\mathrm{Zn}(\mathrm{II})$ on Pestan, an extracellular polysaccharide, of Pestalotiopsis sp. KCTC 8637P. Process Biochem. 41: 312-316.

Ogbonna J.C., H. Mashima and H. Tanaka. 2001. Scale up of fuel ethanol production from sugar beet juice using loofa sponge immobilized bioreactor. Bioresour. Technol. 76: 1-8.

Pan X., J. Wang and D. Zhang. 2005. Biosorption of Pb(II) by Pleurotus ostreatus immobilized in calcium alginate gel. Process Biochem. 40: 2799-2803.

Trujillo E.M., M. Sprinti and H. Zhuang. 1995. Immobilized biomass: a new class of heavy-metal-selective ion exchangers. pp. 225-270. In: Sengupta A.K. (ed). Ion exchange technology: advances in pollution control. Technomic Publishing Co., Pennsylvania. Tsekova K. and G. Petrov. 2002. Removal of heavy metals from aqueous solution using Rhizopus delemar mycelia in free and polyurethane-bound form. Z. Naturforsch. C57: 629-633.

Wilde E.W. and J.R. Benemann. 1993. Bioremoval of heavy metals by the use of microalgae. Biotechnol. Adv. 11: 781-812.

Yakubu N.A. and A.W.L. Dudeney. 1986. Biosorption of uranium with Aspergillus niger. pp. 183-200. In: Eccles H.H. and S. Hunt (eds). Immobilisation of ions by biosorption. Ellis Horwood, Chichester.

Yan G. and T. Viraraghavan. 2003. Heavy metal removal from aqueous solution by fungus Mucur rouxii. Water Res. 37: 4486-4496. 